
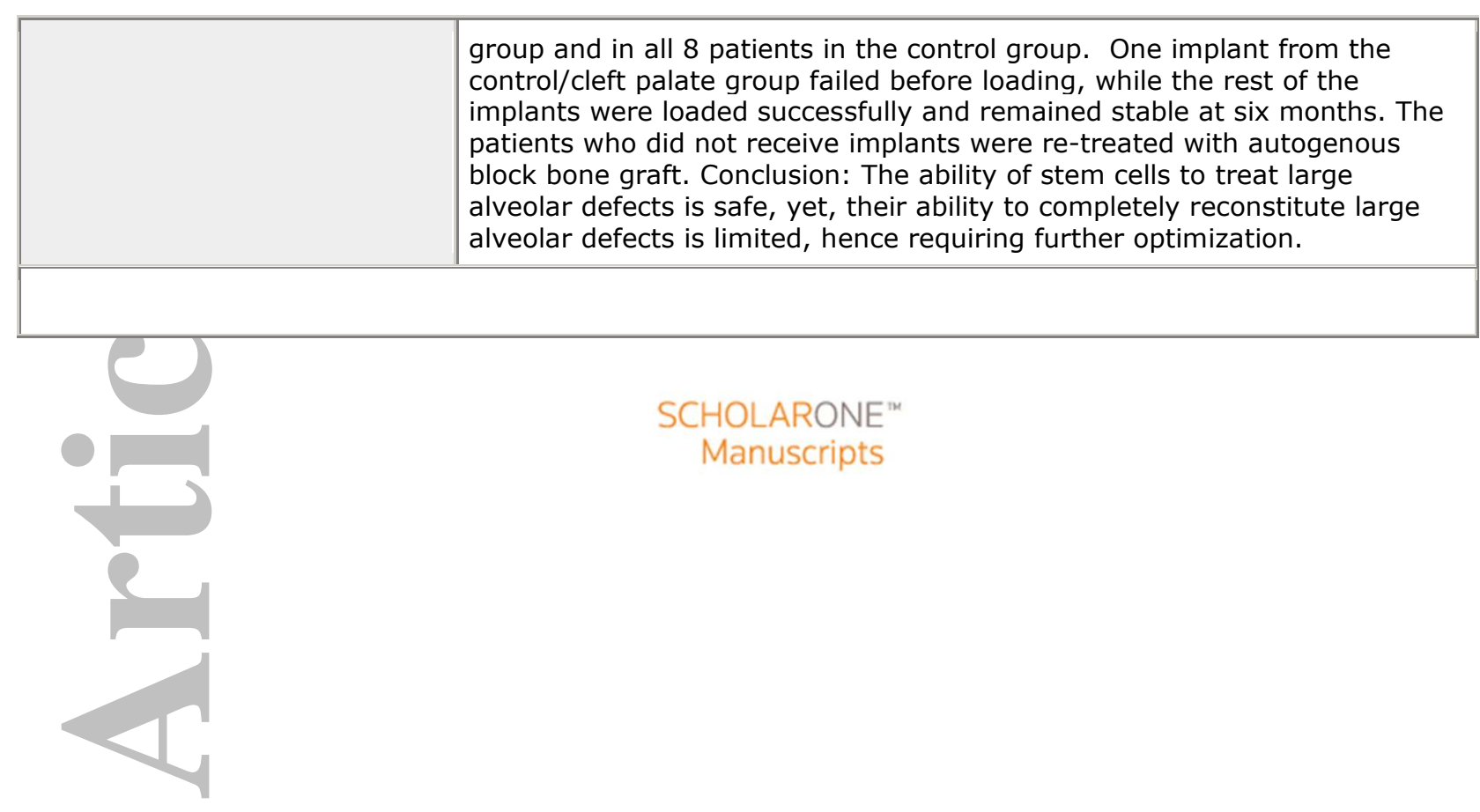

SCHOLARONE ${ }^{\text {M }}$

Manuscripts

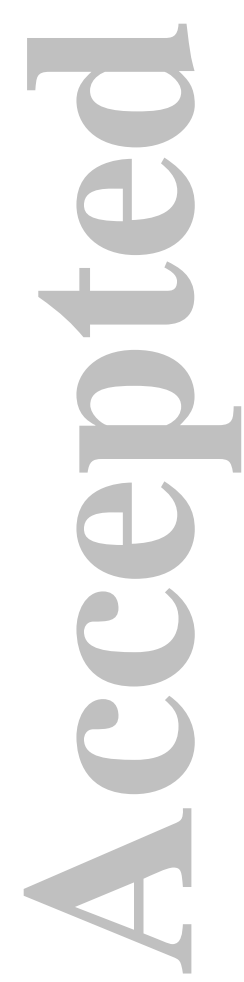

This is the author manuscript accepted for publication and has undergone full peer review but has not been through the copyediting, typesetting, pagination and proofreading process, which may lead to differences between this version and the Version record. Please cite this article as doi:10.1111/ cid.12506. 


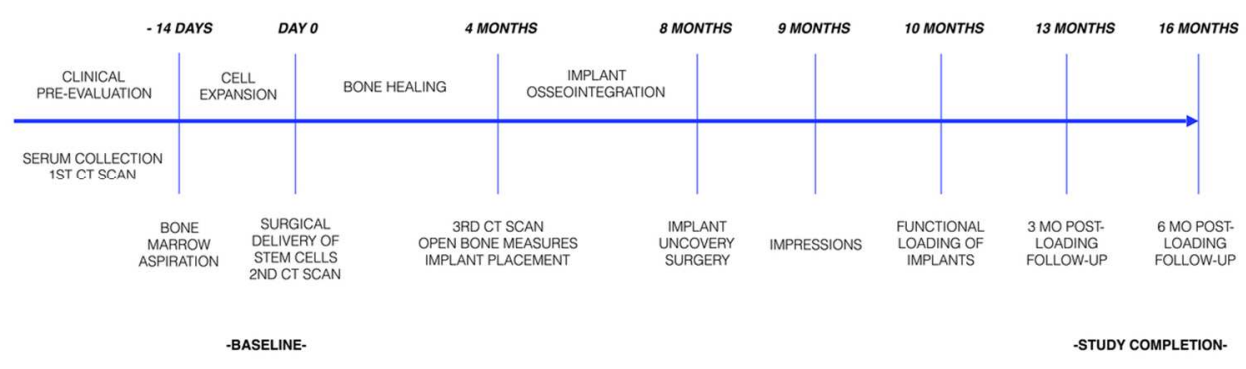

Figure 1. Trial profile. (a) Consort Diagram of patient distribution, (b) Study timeline.

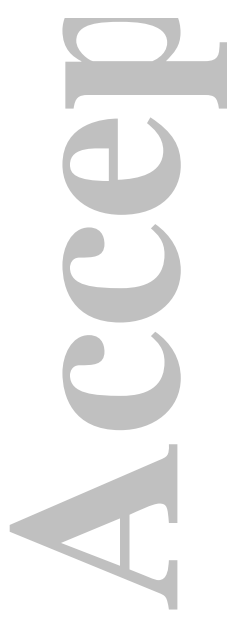

$108 \times 81 \mathrm{~mm}(300 \times 300 \mathrm{DPI})$ 

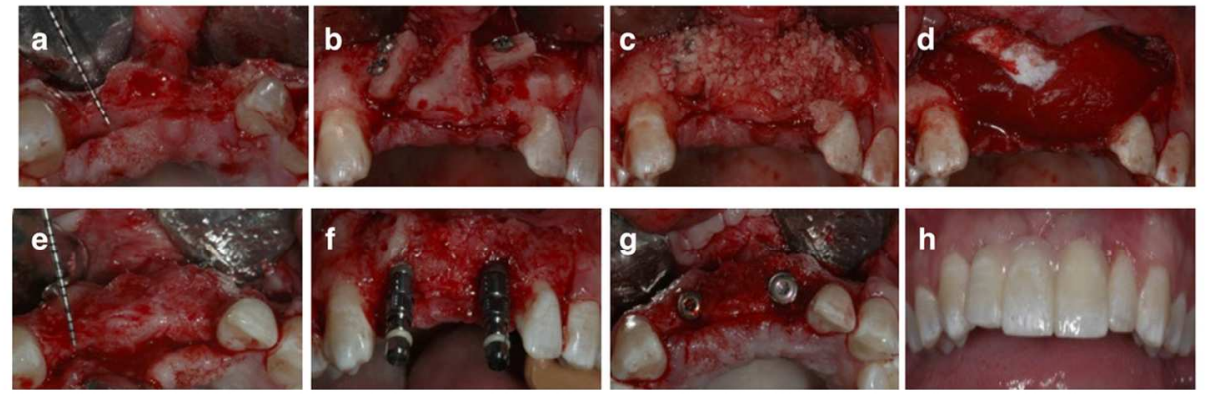

Figure 2. Control case. (a) Horizontal alveolar ridge deficiency in the anterior maxilla. (b) A block graft harvested from the symphysis was fixed with titanium screws (c) The block graft was covered with particulate allograft. (d) The augmented site was further protected with a collagen membrane. (e) Upon reentry at 4 months the occlusal view clearly demonstrates the horizontal gain of bone width. (f,g) Two implants placed in a correct oro-facial position. (h) Final prosthesis delivery

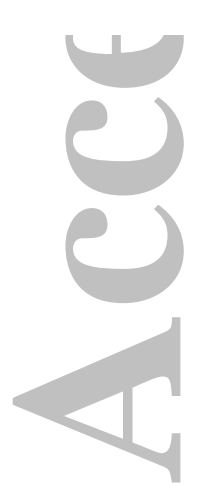

$108 \times 81 \mathrm{~mm}(300 \times 300$ DPI $)$ 

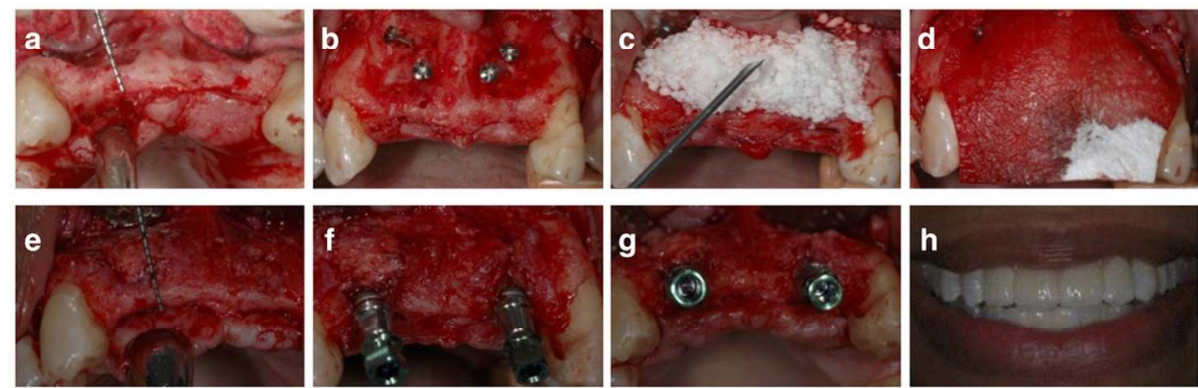

Figure 3. Stem cell therapy case (a) Defect of the anterior alveolar ridge (b) Titanium screws in place. (c,d) Ixmyelocel-t mixed with $\beta$-TCP and covered with collagen membrane. (e) Clinical situation at 4 month reentry. $(f, g)$ Dental implants placed into grafted bone. (h) Final prosthesis delivery

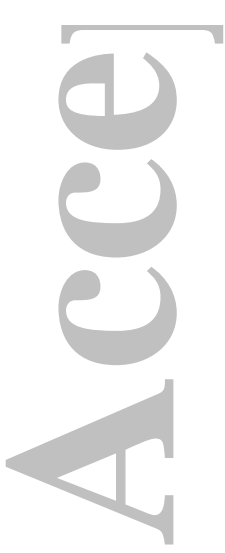

$108 \times 81 \mathrm{~mm}(300 \times 300$ DPI $)$ 


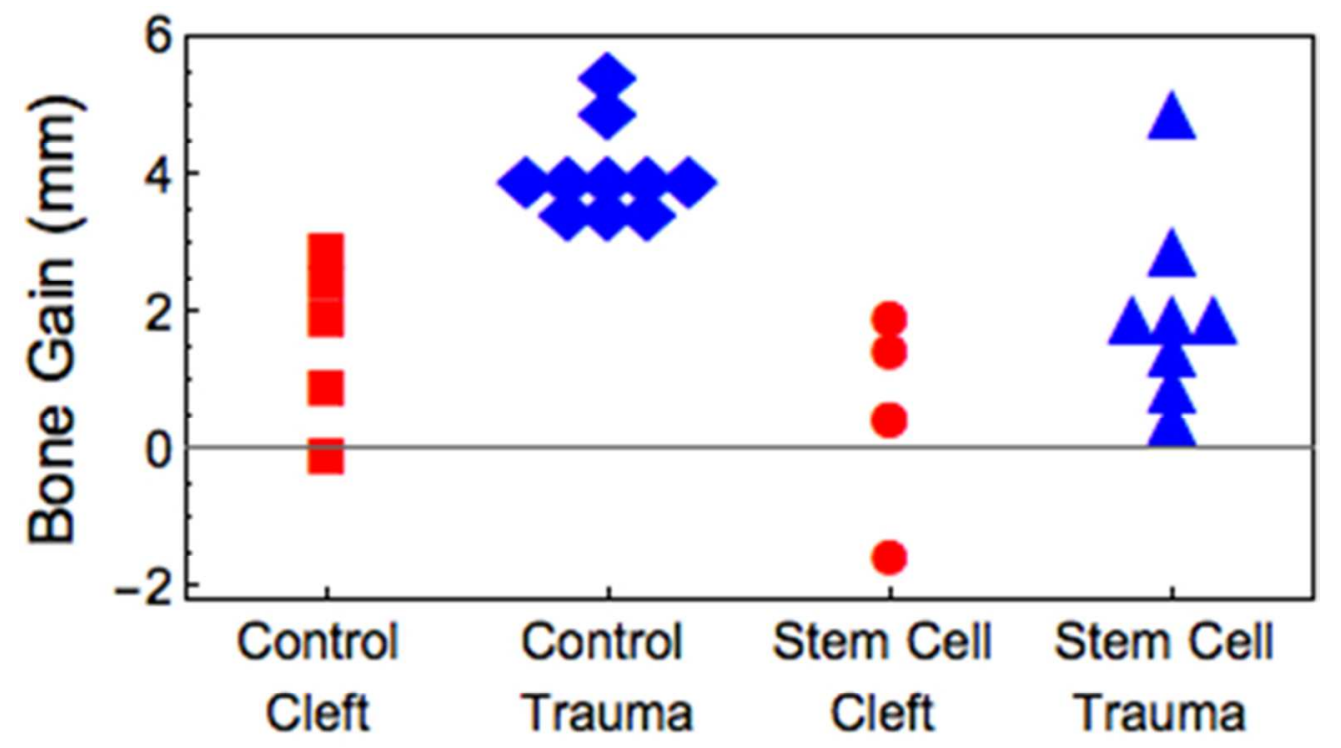

Figure 4. Changes in alveolar ridge width in patients with a history of cleft palate and traumatic injury

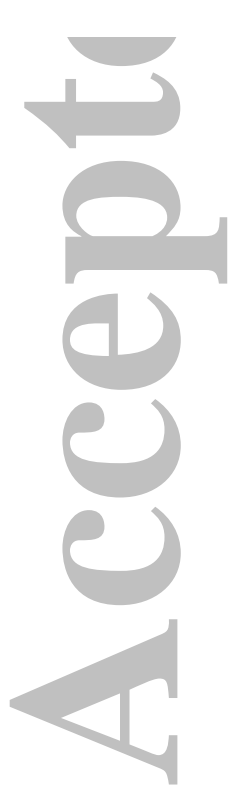

$254 \times 160 m m(72 \times 72$ DPI $)$ 
Table 1. Patient characteristics/demographics

\begin{tabular}{|l|c|c|}
\hline & Control & Stem cell therapy \\
\hline Total number of patients & 8 & 9 \\
\hline $\begin{array}{l}\text { Number of patients } \\
\text { (Trauma/Cleft palate) }\end{array}$ & $5 / 3$ & $5 / 4$ \\
\hline Mean age (Range) & $31(19-54)$ & $27(18-42)$ \\
\hline Gender (Male/Female) & $5 / 3$ & $7 / 2$ \\
\hline Caucasian & & 7 \\
Hispanic & & 1 \\
\hline African American & 6 & 1 \\
\hline \multicolumn{1}{|c|}{ Ethnicity } & 1 & \\
\hline
\end{tabular}

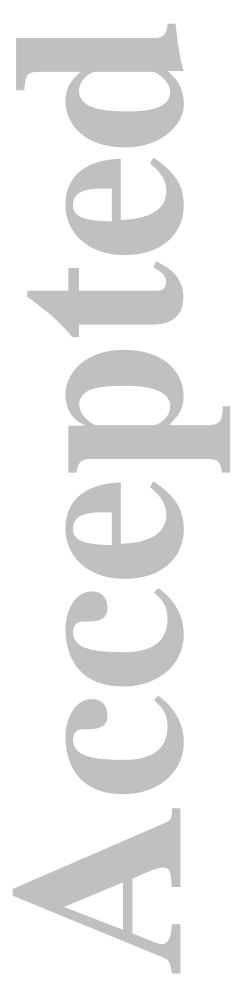


Table 2. Number and location of sites $(n=28)$ to be augmented per patient $(n=17)$

\begin{tabular}{|c|c|c|l|}
\hline Number of sites & n patients & n sites & \multicolumn{1}{|c|}{ Location: $\mathbf{n}$ sites } \\
\hline One site & 7 & 7 & $\begin{array}{l}\text { Maxilla, anterior (incisors, canines): } 5 \\
\text { Mandible, anterior (incisors, canines): } 2\end{array}$ \\
\hline $\begin{array}{c}\text { Two sites } \\
\text { Three sites }\end{array}$ & 1 & 18 & $\begin{array}{l}\text { Maxilla, anterior (incisors, canines): } 14 \\
\text { Mandible, anterior (incisors, canines): } 2 \\
\text { Maxilla, posterior (premolars, molars): } 2\end{array}$ \\
\hline Total & 17 & 28 & $\begin{array}{l}\text { Maxilla, anterior (incisors, canines): } 3 \\
\text { Maxilla, anterior (incisors, canines): } 22 \\
\text { Maxilla, posterior (premolars, molars): } 2 \\
\text { Mandible, anterior (incisors, canines): } 4\end{array}$ \\
\hline
\end{tabular}


Table 3. History of previous surgeries in the area of graft in patients with cleft palate

\begin{tabular}{|l|c|c|}
\hline & Control & Stem cell therapv \\
\hline $\begin{array}{l}\text { Number of previous surgeries related } \\
\text { to cleft palate (mean) }\end{array}$ & 5 & 8 \\
\hline $\begin{array}{l}\text { Number of previous bone grafts } \\
\text { (mean) }\end{array}$ & 2 & 2 \\
\hline Source of previous bone graft & $\begin{array}{c}\text { Iliac crest, tibia, } \\
\text { alveolar bone }\end{array}$ & $\begin{array}{c}\text { Iliac crest, alveolar } \\
\text { bone }\end{array}$ \\
\hline
\end{tabular}

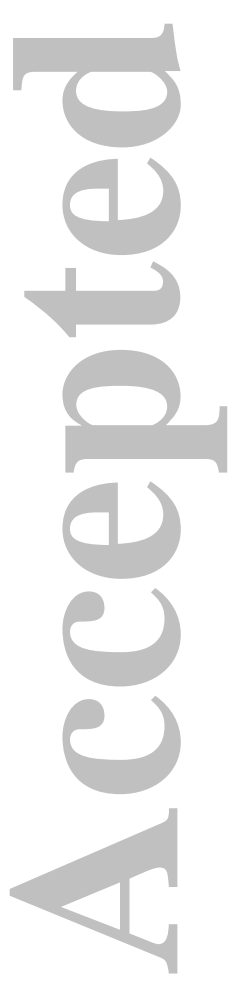


Table 4. Frequency distribution of adverse events

\begin{tabular}{|l|c|c|c|c|}
\hline \multicolumn{1}{|c|}{ Adverse event } & $\begin{array}{c}\text { Control } \\
\text { (Cleft) }\end{array}$ & $\begin{array}{c}\text { Control } \\
\text { (Trauma) }\end{array}$ & $\begin{array}{c}\text { Stem cell } \\
\text { therapy } \\
\text { (Cleft) }\end{array}$ & $\begin{array}{c}\text { Stem cell } \\
\text { therapy } \\
\text { (Trauma) }\end{array}$ \\
\hline Wound dehiscence & 1 & 1 & 1 & \\
\hline Infection & & & 1 & 3 \\
\hline Incision line opening & & & 1 & 1 \\
\hline Membrane exposure & & & & \\
\hline Localized erythema & & 1 & 1 & \\
\hline Localized edema & & & & \\
\hline Tooth sensitivity & & & & \\
\hline Pain and dysesthesia in donor site & & & & \\
\hline $\begin{array}{l}\text { Early suture removal (subject chewing } \\
\text { on surgical site) }\end{array}$ & & & & \\
\hline Early implant failure & & & & \\
\hline Implant supported bridge came off & & & & \\
\hline Abutment screw fracture & & & & \\
\hline
\end{tabular}


Table 5: Clinical measurements of alveolar ridge width in $\mathrm{mm}$

\begin{tabular}{|l|c|c|c|c|c|c|}
\hline $\begin{array}{c}\text { Ridge width in } \\
\text { mm } \\
(\text { mean } \pm \text { SD) }\end{array}$ & $\begin{array}{c}\text { Control } \\
\text { Cleft }\end{array}$ & $\begin{array}{c}\text { Control } \\
\text { Trauma }\end{array}$ & $\begin{array}{c}\text { Control } \\
\text { ALL }\end{array}$ & $\begin{array}{c}\text { Stem } \\
\text { cell } \\
\text { therapy } \\
\text { Cleft }\end{array}$ & $\begin{array}{c}\text { Stem } \\
\text { cell } \\
\text { therapy } \\
\text { Trauma }\end{array}$ & $\begin{array}{c}\text { Stem } \\
\text { cell } \\
\text { therapy } \\
\text { ALL }\end{array}$ \\
\hline Baseline width & $5 \pm 1.1$ & $2.9 \pm 1.3$ & $3.6 \pm 1.6$ & $2.6 \pm 1.6$ & $3.1 \pm 1.1$ & $2.9 \pm 1.3$ \\
\hline Re-entry width & $6.7 \pm 1.6$ & $7 \pm 1.2$ & $6.9 \pm 1.3$ & $3.2 \pm 1.7$ & $5.3 \pm 1.5$ & $4.5 \pm 1.8$ \\
\hline Gain of crest width & $1.7 \pm 1.2$ & $4.1 \pm 0.7$ & $3.3 \pm 1.4$ & $0.6 \pm 1.3$ & $2.1 \pm 1.4$ & $1.5 \pm 1.5$ \\
\hline
\end{tabular}


Table 6: Clinical outcomes

\begin{tabular}{|l|c|c|c|c|}
\hline \multicolumn{1}{|c|}{ Outcome } & $\begin{array}{c}\text { Control } \\
\text { (Cleft) }\end{array}$ & $\begin{array}{c}\text { Control } \\
\text { (Trauma) }\end{array}$ & $\begin{array}{c}\text { Cell } \\
\text { therapy } \\
\text { (Cleft) }\end{array}$ & $\begin{array}{c}\text { Cell } \\
\text { therapy } \\
\text { (Trauma) }\end{array}$ \\
\hline $\begin{array}{l}\text { Patients requiring re-grafting with } \\
\text { block grafts }\end{array}$ & 0 of 3 & 0 of 5 & 3 of 5 & 2 of 5 \\
\hline $\begin{array}{l}\text { Patients reconstructed with implants } \\
\text { Patients requiring additional } \\
\text { grafting at implant placement }\end{array}$ & 0 of 3 & 2 of 5 & 2 of 2 & 1 of 3 \\
\hline
\end{tabular}

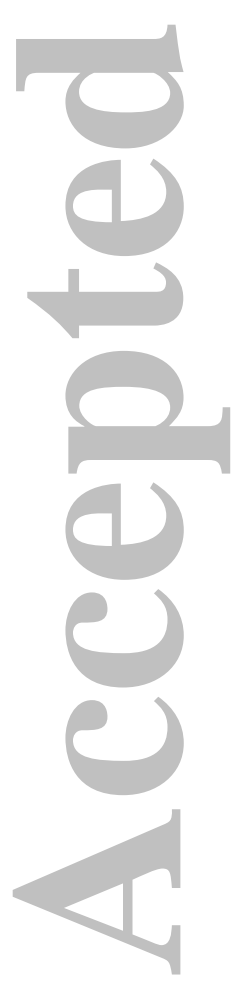


Supplementary Table S1. Adverse event summary

\begin{tabular}{|c|c|c|c|c|c|c|}
\hline $\begin{array}{l}\text { Group TX or } \\
\text { C (control) }\end{array}$ & Subject & Description & Severity & $\begin{array}{l}\text { Related to } \\
\text { study }\end{array}$ & $\begin{array}{l}\text { Related to } \\
\quad \text { cell } \\
\text { treatment }\end{array}$ & $\begin{array}{c}\text { Serious } \\
\mathbf{Y} / \mathbf{N}\end{array}$ \\
\hline C/Trauma & 1 & $\begin{array}{l}\text { Localized } \\
\text { erythema \#6/\#7 }\end{array}$ & Mild & $\begin{array}{l}\text { Definitely } \\
\text { Related }\end{array}$ & Not Related & $\mathrm{N}$ \\
\hline c/Trauma & 2 & $\begin{array}{l}\text { Pain and } \\
\text { dysthesia in } \\
\text { donor site }\end{array}$ & Mild & $\begin{array}{l}\text { Definitely } \\
\text { Related }\end{array}$ & Not Related & $\mathrm{N}$ \\
\hline c/Trauma & 4 & $\begin{array}{l}\text { Subject chewing } \\
\text { on surgical site; } \\
\text { sutures removed } \\
\text { early }\end{array}$ & Mild & $\begin{array}{l}\text { Definitely } \\
\text { Related }\end{array}$ & Not Related & $\mathrm{N}$ \\
\hline C/Trauma & 4 & Left knee pain & Moderate & Not Related & Not Related & $\mathrm{N}$ \\
\hline C/Trauma & 4 & $\begin{array}{l}\text { Self-diagnosed } \\
\text { inflammed } \\
\text { rotator cuff }\end{array}$ & Mild & Not Related & Not Related & $\mathrm{N}$ \\
\hline TX/Trauma & 5 & $\begin{array}{l}\text { Incision line } \\
\text { opening; } \\
\text { resutured site }\end{array}$ & Mild & $\begin{array}{l}\text { Definitely } \\
\text { Related }\end{array}$ & $\begin{array}{l}\text { Possibly } \\
\text { Related }\end{array}$ & $\mathrm{N}$ \\
\hline TX/Trauma & 5 & $\begin{array}{l}\text { Inflammation of } \\
\text { wrist; steroid } \\
\text { injection }\end{array}$ & Moderate & Not Related & Not Related & $\mathrm{N}$ \\
\hline TX/Trauma & 5 & $\begin{array}{l}\text { Wound } \\
\text { dehiscence } \\
\text { caused by early } \\
\text { suture removal, } \\
\text { flap was re- } \\
\text { approximated }\end{array}$ & Mild & $\begin{array}{l}\text { Definitely } \\
\text { Related }\end{array}$ & $\begin{array}{l}\text { Unlikely } \\
\text { Related }\end{array}$ & $\mathrm{N}$ \\
\hline TX/Trauma & 5 & $\begin{array}{l}\text { Implant \#12 in } \\
\text { sinus; implant } \\
\text { removed }\end{array}$ & Moderate & $\begin{array}{l}\text { Definitely } \\
\text { Related }\end{array}$ & Not Related & $\mathrm{N}$ \\
\hline
\end{tabular}




\begin{tabular}{|c|c|c|c|c|c|c|}
\hline $\begin{array}{l}\text { Group TX or } \\
\text { C (control) }\end{array}$ & Subject & Description & Severity & $\begin{array}{l}\text { Related to } \\
\text { study }\end{array}$ & $\begin{array}{l}\text { Related to } \\
\quad \text { cell } \\
\text { treatment }\end{array}$ & $\begin{array}{c}\text { Serious } \\
\mathbf{Y} / \mathbf{N}\end{array}$ \\
\hline TX/Trauma & 6 & $\begin{array}{l}\text { Broke tooth \#13 } \\
\text { while eating; } \\
\text { restoration } \\
\text { recommended }\end{array}$ & Mild & Not Related & Not Related & $\mathrm{N}$ \\
\hline $\mathrm{TX} / \mathrm{T}$ & 6 & $\begin{array}{l}\text { Incision line } \\
\text { opening after } \\
\text { bone graft }\end{array}$ & Mild & $\begin{array}{l}\text { Definitely } \\
\text { Related }\end{array}$ & $\begin{array}{l}\text { Unlikely } \\
\text { Related }\end{array}$ & $\mathrm{N}$ \\
\hline TX/Tra & 7 & $\begin{array}{l}\text { Incision line } \\
\text { opening; }\end{array}$ & Moderate & $\begin{array}{l}\text { Definitely } \\
\text { Related }\end{array}$ & $\begin{array}{l}\text { Possibly } \\
\text { Related }\end{array}$ & $\mathrm{N}$ \\
\hline $\mathrm{TX} / \mathrm{Tr}$ & 7 & Tooth sensitivity & Mild & $\begin{array}{l}\text { Probably } \\
\text { Related }\end{array}$ & $\begin{array}{l}\text { Unlikely } \\
\text { Related }\end{array}$ & $\mathrm{N}$ \\
\hline TX/Trauma & 7 & $\begin{array}{l}\text { Rash on neck } \\
\text { and chest }\end{array}$ & Mild & $\begin{array}{l}\text { Unlikely } \\
\text { Related }\end{array}$ & $\begin{array}{l}\text { Unlikely } \\
\text { Related }\end{array}$ & $\mathrm{N}$ \\
\hline TX/Trai & 7 & $\begin{array}{l}\text { Torn ligament in } \\
\text { ankle }\end{array}$ & Mild & Not Related & Not Related & $\mathrm{N}$ \\
\hline & 9 & $\begin{array}{l}\text { Wisdom teeth } \\
\text { impactions (4) }\end{array}$ & Moderate & Not Related & Not Related & $\mathrm{N}$ \\
\hline TX/Cleft & 9 & $\begin{array}{l}\text { Streptococcal } \\
\text { pharyngitis }\end{array}$ & Mild & Not Related & Not Related & $\mathrm{N}$ \\
\hline TX/Cleft & 9 & $\begin{array}{l}\text { Maxillary } \\
\text { Mucosa } \\
\text { erythema and } \\
\text { edema }\end{array}$ & Mild & $\begin{array}{l}\text { Possibly } \\
\text { Related }\end{array}$ & Not Related & $\mathrm{N}$ \\
\hline C/Trauma & 10 & $\begin{array}{l}\text { Implant } \\
\text { supported } \\
\text { bridge came off; } \\
\text { recemented }\end{array}$ & Moderate & $\begin{array}{l}\text { Definitely } \\
\text { Related }\end{array}$ & Not Related & $\mathrm{N}$ \\
\hline $\mathrm{C} /$ Trauma & 10 & $\begin{array}{l}\text { Unrelated bone } \\
\text { graft procedure } \\
\# 18-19 \text { area }\end{array}$ & Mild & Not Related & Not Related & $\mathrm{N}$ \\
\hline
\end{tabular}




\begin{tabular}{|c|c|c|c|c|c|c|}
\hline $\begin{array}{l}\text { Group TX or } \\
\text { C (control) }\end{array}$ & Subject & Description & Severity & $\begin{array}{l}\text { Related to } \\
\text { study }\end{array}$ & $\begin{array}{l}\text { Related to } \\
\quad \text { cell } \\
\text { treatment }\end{array}$ & $\begin{array}{c}\text { Serious } \\
\mathbf{Y} / \mathbf{N}\end{array}$ \\
\hline TX/Cleft & 11 & $\begin{array}{l}\text { Abutment screw } \\
\text { broke with piece } \\
\text { in implant }\end{array}$ & Mild & $\begin{array}{l}\text { Definitely } \\
\text { Related }\end{array}$ & Not Related & $\mathrm{N}$ \\
\hline & 11 & $\begin{array}{l}\text { Implant crown } \\
\text { came off; } \\
\text { recemented }\end{array}$ & Mild & $\begin{array}{l}\text { Definitely } \\
\text { Related }\end{array}$ & Not Related & $\mathrm{N}$ \\
\hline TX/Cleft & 11 & $\begin{array}{l}\text { Swelling; } \\
\text { unilateral upper } \\
\text { lip from } \\
\text { extended lip } \\
\text { retraction }\end{array}$ & Mild & $\begin{array}{l}\text { Definitely } \\
\text { Related }\end{array}$ & Not Related & $\mathrm{N}$ \\
\hline TX/Trauma & 12 & $\begin{array}{l}\text { Skin rash a few } \\
\text { days following } \\
\text { taking } \\
\text { Amoxicillin }\end{array}$ & Mild & Not Related & Not Related & $\mathrm{N}$ \\
\hline TX/Trauma & 12 & $\begin{array}{l}\text { Moderate } \\
\text { swelling in area } \\
\text { of cheek/right } \\
\text { nostril }\end{array}$ & Mild & $\begin{array}{l}\text { Definitely } \\
\text { Related }\end{array}$ & $\begin{array}{l}\text { Unlikely } \\
\text { Related }\end{array}$ & $\mathrm{N}$ \\
\hline TX/Trauma & 12 & $\begin{array}{l}\text { Implant } \\
\text { supported FPD } \\
\text { came off (\#7- } \\
\# 10) ; \\
\text { recemented }\end{array}$ & Mild & $\begin{array}{l}\text { Definitely } \\
\text { Related }\end{array}$ & Not Related & $\mathrm{N}$ \\
\hline C/Cleft & 14 & $\begin{array}{l}\text { 3mm wound } \\
\text { dehiscence; } \\
\text { inflammed labial } \\
\text { flap }\end{array}$ & Mild & $\begin{array}{l}\text { Definitely } \\
\text { Related }\end{array}$ & Not Related & $\mathrm{N}$ \\
\hline C/Cleft & 14 & $\begin{array}{l}\text { Several ulers } \\
\text { adjacent to \#10 } \\
\text { area on labial } \\
\text { mucosa }\end{array}$ & Mild & $\begin{array}{l}\text { Unlikely } \\
\text { Related }\end{array}$ & Not Related & $\mathrm{N}$ \\
\hline
\end{tabular}




\begin{tabular}{|c|c|c|c|c|c|c|}
\hline $\begin{array}{l}\text { Group TX or } \\
\text { C (control) }\end{array}$ & Subject & Description & Severity & $\begin{array}{l}\text { Related to } \\
\text { study }\end{array}$ & $\begin{array}{l}\text { Related to } \\
\quad \text { cell } \\
\text { treatment }\end{array}$ & $\begin{array}{c}\text { Serious } \\
\text { Y/N }\end{array}$ \\
\hline TX/Cleft & 15 & $\begin{array}{l}\text { Implant \#7 } \\
\text { failing due to } \\
\text { bone loss (non- } \\
\text { study implant) }\end{array}$ & Mild & Not Related & Not Related & $\mathrm{N}$ \\
\hline & 15 & Hernia & Moderate & Not Related & Not Related & $\mathrm{N}$ \\
\hline TX/Cleft & 15 & $\begin{array}{l}\text { Car accident; } \\
\text { subject } \\
\text { hospitalized for } \\
3 \text { days }\end{array}$ & Severe & Not Related & Not Related & Y \\
\hline C/Cleft & 17 & $\begin{array}{l}\text { Pain on left side } \\
\text { radiating to the } \\
\text { joint (TMJ); } \\
\text { ongoing } \\
\text { sensitivity which } \\
\text { could be } \\
\text { associated with } \\
\text { pain; sinus } \\
\text { infections }\end{array}$ & Severe & $\begin{array}{l}\text { Possibly } \\
\text { Related }\end{array}$ & Not Related & $\mathrm{N}$ \\
\hline $\mathrm{C} / \mathrm{Cleft}$ & 17 & $\begin{array}{l}\text { Implant failure } \\
\# 10 ; \text { not } \\
\text { osseointegrated }\end{array}$ & Moderate & $\begin{array}{l}\text { Definitely } \\
\text { Related }\end{array}$ & Not Related & $\mathrm{N}$ \\
\hline & 17 & $\begin{array}{l}\text { No bone root } \\
\text { surface \#9; } \\
\text { extracted }\end{array}$ & Moderate & $\begin{array}{l}\text { Definitely } \\
\text { Related }\end{array}$ & Not Related & $\mathrm{N}$ \\
\hline & 18 & $\begin{array}{l}\text { Membrane } \\
\text { exposed/flap } \\
\text { mobility }\end{array}$ & Mild & $\begin{array}{l}\text { Definitely } \\
\text { Related }\end{array}$ & $\begin{array}{l}\text { Unlikely } \\
\text { Related }\end{array}$ & $\mathrm{N}$ \\
\hline TX/Cleft & 19 & $\begin{array}{l}\text { Suppuration at } \\
\text { wound site; } \\
\text { wound } \\
\text { dehiscence }\end{array}$ & Mild & $\begin{array}{l}\text { Definitely } \\
\text { Related }\end{array}$ & Not Related & $\mathrm{N}$ \\
\hline
\end{tabular}




\section{Stem cell therapy for reconstruction of alveolar cleft and trauma defects in adults: A randomized controlled, clinical trial}

Mona Bajestan, DDS ${ }^{1}$; Archana Rajan, DDS ${ }^{1}$; Sean P. Edwards, DDS, MD ${ }^{2}$; Sharon Aronovich, DMD ${ }^{2}$; Lucia H.S. Cevidanes, PhD, DDS ${ }^{1}$; Angeliki Polymeri, DDS ${ }^{3}$; Suncica Travan, DDS ${ }^{3}$; Darnell Kaigler, PhD, DDS ${ }^{3,4}$

${ }^{1}$ Department of Orthodontics and Pediatric Dentistry, School of Dentistry, University of Michigan; Ann Arbor, Michigan, USA

${ }^{2}$ Department of Oral and Maxillofacial Surgery, School of Dentistry, University of Michigan; Ann Arbor, Michigan USA

${ }^{3}$ Department of Periodontics and Oral Medicine, School of Dentistry, University of Michigan; Ann Arbor, Michigan USA

${ }^{4}$ Department of Biomedical Engineering, College of Engineering, University of Michigan; Ann Arbor, Michigan USA

Mona Bajestan and Archana Rajan contributed equally to this work.

The authors report no conflict of interest.

Author Contributions:

Mona Bajestan and Archana Rajan: study concept/design, data collection, data analysis/interpretation, drafting article, statistics, critical revision of article, article approval

Sean P. Edwards: study concept/design, data collection, data analysis/interpretation, critical revision of article, article approval, funding

Sharon Aronovich: study concept/design, data collection, data analysis/interpretation, critical revision of article, article approval

Lucia H.S. Cevidanes: data collection, data analysis, critical revision of article, article approval

Angeliki Polymeri: data analysis/interpretation, drafting article, critical revision of article, article approval

Suncica Travan: data collection, data analysis/interpretation, critical revision of article, article approval

Darnell Kaigler: study concept/design, data collection, data analysis/interpretation, drafting article, statistics, critical revision of article, article approval, funding

Corresponding Author: Darnell Kaigler, 1011 N. University St, Ann Arbor MI, 48109, USA Tel: +1-734-615-4023, Email: dkaigler@umich.edu

Key Words: trauma, cleft, stem cells, reconstruction, bone regeneration, cell therapy, dental implants, clinical trial 


\section{ABSTRACT}

Background: Stem cell therapy with bone marrow-derived mesenchymal stem cells is a promising tissue engineering strategy to promote regeneration of craniofacial bone.

Purpose: To determine whether cell therapy with ex vivo expanded stem cell populations would be safe and efficacious in the regeneration of large alveolar defects in patients with a history of cleft palate or craniofacial trauma.

Materials and Methods: 18 patients (10 patients with traumatic injury and 8 patients with cleft palate) presenting with missing teeth associated with horizontal alveolar bone deficiencies were included in this randomized controlled clinical trial. Patients were randomized to receive either conventional autogenous block grafts or stem cell therapy. After a healing period of 4 months the treated sites were re-entered and the bone width re-assessed prior to implant placement. Implant stability was evaluated through torque testing of the implant upon insertion and at 6 months postloading.

Results: The mean gain in bone width was $1.5 \pm 1.5 \mathrm{~mm}$ in the stem cell therapy group and 3.3 $\pm 1.4 \mathrm{~mm}$ in the control group. Overall, bone gain was higher in trauma patients as compared to patients with cleft palate, for both the control and the stem cell therapy groups. Most postoperative complications were wound dehiscences and incision line openings. Implants were placed successfully in 5 out of 10 patients in the stem cell therapy group and in all 8 patients in the control group. One implant from the control/cleft palate group failed before loading, while the rest of the implants were loaded successfully and remained stable at six months. The patients who did not receive implants were re-treated with autogenous block bone graft. Conclusion: The ability of stem cells to treat large alveolar defects is safe, yet, their ability to completely 
reconstitute large alveolar defects is limited. This approach requires further optimization to meet the outcomes seen using current methods to treat large defects, particularly those resultant of cleft palate.

\section{INTRODUCTION}

Oral and craniofacial bone defects secondary to congenital diseases (e.g. orofacial clefts) and trauma are very common and represent a significant health care burden. ${ }^{1}$ Clefts of the lip and palate represent the most common congenital malformations of the head and neck, with approximately 7,000 infants born with orofacial clefts in the U.S. annually. The prevalence of cleft lip with or without cleft palate is 10.89 per 10,000 live births, and that of cleft palate is 6.45 per 10,000 live births. ${ }^{2}$ Patients with clefts of the maxillary alveolus are frequently missing teeth, typically the lateral incisors, either unilaterally or bilaterally. ${ }^{3}$ Regarding trauma, the vast majority of facial traumatic injuries are attributed to motor vehicle accidents, falls, assaults, recreational and sports injuries ${ }^{4}$. Edentulous areas with large alveolar defects are also observed in trauma related injuries of the orofacial complex. $4.1 \%$ of all emergency room visits are attributed to primary traumatic injuries to the head and neck region; injuries to teeth and dental structures are quite common in these patients. ${ }^{5}$

In such cases of severe alveolar deficiencies, implant-prosthetic treatment involving advanced bone grafting techniques is generally indicated to restore optimum function and improve compromised esthetics. Currently, autogenous block bone grafts from intraoral (ramus, mandibular symphysis) or extraoral sites (iliac crest, tibia) represent the standard-ofcare for alveolar grafting in cleft palate and trauma patients. ${ }^{6}$ However, harvesting bone from an additional donor site has several potential disadvantages including longer surgical time, 
prolonged recovery, and morbidity at the donor site including pain and neurosensory disturbances.

In an effort to overcome the limitations of current bone augmentation procedures, cell therapy by means of cell transplantation has emerged as a possible strategy to regenerate alveolar bone. Recently, there have been several clinical reports evaluating the use of stem cells as a promising alternative approach for the reconstruction of alveolar bone defects. ${ }^{7-11} \mathrm{We}$ have previously demonstrated that the use of autologous mixed cell populations containing stem cells enhance and accelerate healing and regeneration of bone. ${ }^{9}$ Due to success in regenerating localized bone defects, the aim of this study was to evaluate this approach for larger, more challenging alveolar defects.

This phase $1 / 2$ feasibility trial had two objectives. The first was to examine the safety and efficacy of an autologous cell therapy using a mixed population of expanded autologous progenitor and stem cells (ixmyelocel-t, Aastrom Biosciences, Inc.) to regenerate alveolar bone in patients with alveolar defects resultant of cleft palate or trauma. The second objective was to determine whether ixmyelocel-t therapy could regenerate bone sufficient to enable the stable installation of dental implants.

\section{METHODS}

\section{Study design, patient selection, and randomization}

After US Food and Drug Administration and University of Michigan Institutional Review Board (IRB) approval, 20 (twenty) subjects who had horizontal alveolar ridge atrophy secondary to clefts $(n=10)$ or trauma $(n=10)$, were selected to participate in this phase $1 / 2$ randomized, controlled clinical trial. This sample size was chosen for feasibility rather than statistical 
precision. Patients were fully informed about the surgical procedures and treatment alternatives and signed an informed consent. Following the screening examination performed by an examiner, if the subjects met all inclusion and exclusion criteria, they were enrolled by the study coordinator (Supplemental study protocol document). A computer-generated randomization schedule was used to randomly assign eligible subjects from each of the two groups (cleft or trauma) to receive one of two possible treatments, either traditional autogenous bone grafting or stem cell therapy (ixmyelocel-t) (Figure 1a). Due to the nature of the stem cell therapy group requiring bone marrow aspiration, patient and surgeon blinding was not possible. Preoperative analyses included a complete medical history, blood draw for lab studies (liver/renal panel, CBC), a clinical and radiographic examination of the stomatognathic system and a thorough evaluation of the implant-recipient site with a cone-beam computed tomography (CBCT) scan. The study timeline is outlined in Figure1b. The primary outcome of the study was the change in ridge width at re-entry which was assessed clinically with open bone measures and radiographically with $\mathrm{CBCT}$. The measures were calculated between the baseline bone width and the bone width of the healed ridge. Secondary outcomes included: (i) the number of patients who required re-grafting, (ii) the short-term implant survival, and (iii) patient centered outcomeslife quality assessment.

\section{Ixmyelocel-t production}

In the study participants who were designated to be in the stem cell therapy group, 12-14 days before initial surgical treatment, 30-50 $\mathrm{ml}$ of bone marrow was aspirated from the posterior iliac crest under conscious sedation and local anesthesia. Cell processing for generation of the autologous cell product, ixmyelocel-t (Aastrom Biosciences Inc., Ann Arbor, MI, USA), has 
been previously described. ${ }^{12}$ Briefly, the collected marrow was transferred to a sterile blood bag and bone marrow mononuclear cells (BMMNC) were purified by Ficoll density gradient centrifugation. BMMNC were then inoculated into a bioreactor, which is a proprietary computercontrolled, automated cell-processing unit, the Aastrom Replicell System (Aastrom Biosciences). This system incorporates single-pass perfusion in which fresh medium flows slowly over the cells without retention of waste metabolites or differentiating cytokines. The culture medium consists of Iscove's modified Dulbecco's medium (IMDM), 10\% fetal bovine serum, 10\% horse serum, and $5 \mathrm{mM}$ hydrocortisone. After cultivation for 12 days at $37^{\circ} \mathrm{C}, 5 \% \mathrm{CO} 2$, with a ramped continuous medium perfusion schedule, the Ixmyelocel-t product was harvested by trypsinization, washed in a physiologic buffer, and collected into a sterile bag, where it was stored until the time of transplantation. The final cell composition was composed of a mixture of bone marrow-derived cells, including different concentrations of expanded CD90+ mesenchymal stem cells, CD14+ monocytes/ macrophages, and mononuclear cells from the original bone marrow aspirate. The final cell product was suspended in Isolyte and $0.5 \%$ human serum albumin, and transported in a sterile bag to the surgical suite.

\section{Bone regenerative procedure}

12-14 days after the bone marrow aspiration, alveolar grafting was performed with the cell therapy (ixmyelocel-t) or an autogenous bone block harvested from an intraoral site (Figures 2 and 3). In all patients, the surgery was performed under conscious sedation as well as local anesthesia. Two surgeons performed all the surgeries. All cleft surgeries were performed by the same surgeon while all trauma surgeries were performed by the same surgeon. Full thickness mucoperiosteal flaps were raised on the facial and palatal/lingual aspects of the bone defects. 
The alveolar crest width was measured with a vernier caliper to the nearest half of a millimeter, 3 mm below the crest (baseline width). Using a small round bur, the facial cortex was decorticated to open up the bone marrow spaces in the defect site to facilitate graft integration.

In the control sites, a cortico-cancellous block bone graft was harvested from the mandibular ramus or symphysis region. The size of the graft was based on the size of the alveolar bone defect. Once the graft was sized appropriately for ideal bone contact, fixation was achieved with positional bone screws. Voids around the block graft were filled with allogeneic particulate bone graft (either freeze dried bone allograft or Puros cortical allograft, Zimmer). The particulate graft was stabilized in the site with a collagen barrier membrane (CollaTape, Zimmer). For the stem cell therapy group, a unit dose ${ }^{1}$ of Ixmyelocel-T $(10 \mathrm{ml})$ was mixed with a commercially available $\beta$-TCP (beta tricalcium phosphate; Cerasorb), which was used as a carrier to deliver the cells. The number of cells mixed per unit volume of $\beta$-TCP was within the optimum range as determined in preclinical studies $\left(15 \times 10^{6}-44 \times 10^{6}\right.$ Ixmyelocel-T $\left./ \mathrm{ml}\right)$. The amount of $\beta$-TCP used ranged from 2.0-5.0 cc for each patient. The total amount of $\beta$-TCP used depended on the number of Ixmyelocel-T grafted, with the final dosage being $15-44 \times 10^{6}$ Ixmyelocel-T/cc $\beta$ TCP. A resorbable cross-linked collagen membrane (ConForm; ACE surgical) was placed for graft containment and secured with membrane tacks or screws. The labial flap was mobilized via periosteal scoring incisions and supra-periosteal dissection. The flaps were then repositioned and approximated with bioabsorbable sutures in a tension-free manner. Primary closure was obtained in all cases.

\footnotetext{
${ }^{1}$ A unit dose of IXMYELOCEL-T is the cells produced from a single run patient batch derived from an inoculum of $255 \times 10^{6}$ cells into a standard AastromReplicell Cell Cassette processed in the current version of the AastromReplicell System.
} 


\section{Post-Operative Care}

Oral hygiene instructions included $0.12 \%$ Chlorhexidine mouth rinses and no brushing in the surgical area for 2 weeks, to reduce the risk of oral infection. Patients were prescribed oral antibiotics (Amoxicillin $500 \mathrm{mg}$ every $8 \mathrm{~h}$ for 7 days), and ibuprofen $600 \mathrm{mg}$ (every 6 hours for 3 days). Follow-up examinations were performed at two weeks and at 4 weeks following surgery. Patients were next seen for re-entry and implant placement at 4 months.

\section{Re-entry}

Re-entry procedures of the grafted sites were performed at 4 months post-grafting. Prior to reentry, another CBCT was recorded for surgical planning of the implant placement to evaluate the extent of augmentation. Following mucoperiosteal flap elevation and debridement, the healed crest width was measured again with a caliper (re-entry width). Dental implants (Straumann, Nobel Biocare, Implant Direct, Zimmer) of appropriate size were placed in the regenerated sites only in cases where sufficient bone was present and primary implant stability could be achieved. If primary stabilization of an implant could not be achieved, additional grafting was performed using the same standard of care procedure as in the control group and the area was allowed to heal for an additional 4 month period, before being re-entered for implant installation. In cases where primary stability was achieved but residual bone deficiencies remained at the time of implant placement causing implant thread exposure, additional bone grafting was performed with freeze dried bone allograft (FDBA) in combination with a collagen membrane (conForm, ACE).

\section{Short-term implant survival}


The ability of the dental implant fixtures to remain stable was evaluated at six months postloading. Implants were considered failures if they did not osseointegrate in the regenerated bone prior to loading with the final prosthesis or if they developed fibrous encapsulation following loading. Osseointegration was evaluated based on clinical implant stability (primary stability upon implant placement, as well as torque testing) and radiographic examination.

\section{Statistical analyses}

Descriptive statistics were used to summarize and describe the data. No statistical test was implemented to evaluate differences in bone gain between the groups due to the small sample size. Additionally, no direct comparison of adverse events among the groups was performed. Values are presented as means \pm s.d.

\section{RESULTS}

A total of 18 patients were enrolled and 17 completed the study. Based on the compromised clinical outcomes observed in patients who received the cell therapy in the cleft group, enrollment was held to 8 patients for this cohort. The baseline demographic characteristics of all study participants are displayed in Table 1. In each patient, from one to three sites were treated; as such, a total of 28 sites were grafted (Table 2). Table 3 illustrates the previous surgical procedures that were performed in the cleft palate patients. Note that in the cleft cohort, only 8 of the originally planned 10 patients were enrolled because the compromised clinical outcomes seen in the treatment group (cell therapy) relative to the control group in this cohort contraindicated additional participant accrual.

No serious, study related adverse events were reported in examination of comprehensive safety assessments during the trial (Table 4). Most postoperative complications were wound 
dehiscences and this occurred in 2 patients (one from control/cleft group, and one from cell therapy/cleft group ), with symptoms of infection present in the cell therapy/cleft patient. In three patients from the stem cell therapy trauma group the surgical sited had to be re-sutured because of incision line opening. In one patient who received a symphysis graft, mild pain and dysthesia of the donor site were reported after the procedure and the symptoms resolved within one week. Other postoperative complications included mild edema and erythema in the surgical site, tooth sensitivity and prosthesis related complications. The complete description of each reported adverse events is presented in Supplementary Table S1.

Pre-operative ridge dimensions and changes for the different groups are presented in Table 5. The mean width of the initial alveolar ridge was $3.6 \pm 1.6 \mathrm{~mm}$ for the control group and $2.9 \pm 1.3$ $\mathrm{mm}$ for the stem cell therapy group. At re-entry, the healed augmented alveolar crest had a mean width of $6.9 \pm 1.3 \mathrm{~mm}$ for the control group and $4.5 \pm 1.8 \mathrm{~mm}$ for the stem cell therapy group. The mean calculated gain of horizontal ridge augmentation was $3.3 \pm 1.4 \mathrm{~mm}$ and $1.5 \pm 1.5 \mathrm{~mm}$ for the control and cell therapy group respectively. One patient with cleft palate who received the stem cell therapy presented with $1.5 \mathrm{~mm}$ loss of alveolar bone width at re-entry. All the other patients with cleft palate who received the ixmyelocel-t gained from 0.5 to $2 \mathrm{~mm}$ of bone width. The respective gain in bone width for the patients with trauma was from 0.5 to $5 \mathrm{~mm}$. The mean bone gain was higher in trauma patients as compared to cleft palate patients for both the control and stem cell therapy group (Fig. 4).

Augmented sites allowed for proper implant placement in all eight patients of the control group and in five out of ten patients of the stem cell therapy group. Two of those five patients of the stem cell therapy group who received implants belonged to the cleft palate group and and the remaining three belonged to the trauma group. The patients who did not receive implants were 
re-treated with autogenous block bone graft and were allowed to heal for an additional period of 4 months (Table 6). Among the patients that received implants additional bone augmentation procedures were performed in two control patients and three Ixmyelocel-T patients. The additional bone augmentation procedures included the use of either autogenous bone chips or freeze dried bone allograft (FDBA) in combination with a collagen membrane (conForm, ACE or Zimmer).

One implant from the control/cleft palate group did not achieve osseointegration and had to be removed. The rest of the implants were loaded successfully and remained stable at three and six months post loading. The abutments were well adapted to the implant fixture and the restorations were functional.

In order to assess whether the cell transplantation treatment affected the quality of life of the patients, all subjects were asked to complete a questionnaire at the end of the study (Supplementary table S2). Two patients from the control group reported that the procedure resulted in significant discomfort and another two that the procedure interfered with the daily activities. The results were similar in the stem cell therapy group where two patients reported that the procedure resulted in significant discomfort and another two that the procedure interfered with the daily activities. Subjects from both groups reported that they were satisfied with the outcome of the procedure, would recommend this procedure to other individuals, and would do it again if necessary.

\section{DISCUSSION}

Our clinical trial was designed to evaluate the safety and efficacy of an autologous stem cell therapy for the regeneration of large, complex alveolar bone defects. Though the prospect of stem cell therapies offers significant advantages over traditional approaches for oral and 
craniofacial reconstruction, there has been very limited translation of this work toward clinical applications. One of the major limitations lies in the inadequate characterization, as well as the variability in the methods of isolation and ex vivo expansion of the cell populations. ${ }^{9}$ A defining element of ixmyelocel-t therapy is the ability to employ reproducible cell isolation and expansion protocols that can predictably yield consistent cell populations, characterized by the presence of CD90+ mesenchymal stem cells, CD14+ monocytes/ macrophages, and mononuclear cells. ${ }^{8}$

Bone marrow osteoprogenitor cell delivery via local injection has been used in orthopedics for a number of years for the treatment of non-union and critical-sized segmental defects. ${ }^{13}$ Besides the local injection of SSCs into the site of injury, other methods of cell transplantation include the use of various carriers such as demineralized bone matrix or hydroxyapatite scaffolds. ${ }^{14}$ Ex vivo expanded SSCs loaded onto resorbable scaffolds have been successfully used in the treatment of idiopathic osteonecrosis of the femoral head, "critical-sized" long bone defects, spinal fusion and total hip arthroplasty. ${ }^{15-17}$ Outside of orthopaedics, there are limited reports of bone marrow derived mesenchymal stem cells being used for the treatment of craniofacial bone defects arising from trauma and congential defects, ${ }^{7,10,18}$; yet, no randomized controlled clinical trial involving implant therapy has been reported.

The results of the current clinical study showed that this cell therapy is capable of osseous regeneration, confirming the results of our previous randomized controlled clinical studies where ixmyelocel-t therapy was evaluated in bone regeneration of extraction sockets and bone reconstruction of maxillary sinuses. ${ }^{8,9,11}$ In the present study however, the ability of these cells to completely reconstitute a large craniofacial defect was limited, particularly in the patients with cleft palate. It is well-established that in patients with large cleft lip and palate deformities, sufficient mucosa of adequate vascularity is typically missing owing to the nature of the defect 
itself or to scarring from prior surgical procedures. ${ }^{19,20}$ Scar tissue may have a poor blood supply with low oxygen tension, and when it is used to cover a bone graft, healing can be compromised. $^{21,22}$ These are important considerations in the cleft palate cohort of this study. All of the patients with a history of alveolar clefting had already undergone at least five prior surgical procedures at the defect site, and in some instances more than eight hard or soft tissue surgical procedures (Table 3). These sites exhibited palatal and labial mucosal scaring, along with dense fibrous and hypovascular submucosal tissue. These variables created significant surgical challenges and ultimately impacted the clinical outcomes of the bone grafting procedures.

Success of the bone augmentation procedure is defined as the ability to place implants with adequate primary stability. In our study, horizontal bone augmentation was successful in three of five patients who received cell therapy for the treatment alveolar defects secondary to trauma. The cell therapy for treatment of alveolar cleft was successful in two out of five subjects.

One of the other important factors for successful bone tissue regeneration is the ability to maintain space over the grafted bone, which allows the formation of an undisturbed blood clot and healing. ${ }^{23}$ Several techniques that have been used to maintain the space in non-containing large alveolar defects include the use of graft materials such as autogenous block grafts or mineralized particulate bone grafts, as well as titanium tenting screws. ${ }^{24-26}$ In the present study the carrier for stem cells was ß-TCP in a granular form, of which $90 \%$ has been shown to resorb in 3 months. ${ }^{27,} 28$ This matrix carrier may be suitable for smaller more localized defects but for larger defects, may not be suitable due to collapse within the defect, leading to a suboptimal regenerative outcome in the stem cell treatment group. Our goal was to compare the efficacy of the cell transplantation therapy using particulate $\beta$-TCP as a carrier to the standard of care 
procedure for the regeneration of large alveolar defects. Therefore, our control treatment did not include the carrier alone (ß-TCP), but the use of autologous block bone graft which is considered the standard of care for large alveolar defects. ${ }^{6}$

Another limitation of predictable bone regeneration in these challenging defects might be due to the inability to "tailor" the delivery of cells to the shape variability of patient-specific defects. Pre-clinical studies using human bone marrow mononuclear cells or human bone marrow derived mesenchymal stem cells have shown that the seeding efficacy on $\beta$-TCP is generally high and cells stay attached to $\beta$-TCP for 3 weeks although differences exist between various HA/TCP ratios. $^{29,} 30$ To our knowledge no preclinical studies have assessed the adhesion of the ixmyelocel-t cells on $\beta$-TCP. It is therefore possible that the cells may have migrated out of the defect and therefore not have contributed to regeneration. Alternatively, an ideal approach would be one that is standardized enough to be reproducible, yet adaptable enough to be patient- and defect-specific. Future studies should consider stem cell transplantation on 3-dimensional (3-D) printed scaffolds produced in the morphological dimensions of patient-specific craniofacial defects. $^{31,32}$

Post-operative evaluation time is another element that has a great variation in different studies. Generally, healing time for large guided bone regeneration procedures has been reported to be between 5 and 13 months. ${ }^{33-36}$ The rationale for our choosing the 4-month time point for re-entry was based on the results of previous study on using autologous cell therapy for reconstruction of localized craniofacial defect. ${ }^{8}$ In that study it was shown that autologous cell therapy therapy accelerates wound repair in extraction sockets, however, in larger defects, these processes may require longer healing periods with this approach. 
Besides evaluating the safety and efficacy of this new approach, we also aimed to acquire information relative to the treatment protocol from the patient perspective. This quality-of-life assessment is often overlooked or not reported when trying to determine the initial feasibility of emerging therapies; yet, if the therapy is deemed effective, these factors could underscore the acceptance and widespread use of these procedures. Our study found that the acceptance of the cell therapy is similar to the acceptance of the conventional treatment with autogenous block graft. Most patients reported that the procedures involved did not result in significant discomfort and did not significantly impact their daily life activities. All participants from both groups reported that they were satisfied with the final outcome and that if necessary, they would undergo them again. This is in contrast with other studies reporting that most patients would not elect to undergo bone regeneration procedures with autogenous grafts again if necessary because of the associated postoperative pain and distress. ${ }^{37}$

\section{CONCLUSIONS}

Our study demonstrated that transplantation of autologous stem cells can be used safely for the reconstruction of large craniofacial defects. Although the ability of ex-vivo expanded autologous stem cells to completely reconstitute a large alveolar defect in adults is limited, these cells are capable of osseous regeneration. This study provided insight into factors that are critical for successful bone regeneration. Considerations for future investigations would include longer postoperative evaluation time periods, different scaffold material, and mode of delivery techniques which could potentially utilize customized scaffold/matrix designs. Larger multi-center randomized controlled clinical trials are necessary for the widespread use of this approach to enhance bone regeneration in large alveolar and craniofacial defects. 


\section{ACKNOWLEDGEMENTS}

The authors attest that there are no conflicts of interest associated with this work. This study was funded by a Career Award for Medical Scientists from the Burroughs Wellcome Fund, the OralMaxillofacial Surgery Foundation, and the Michigan Institute for Clinical Health Research (MICHR) Clinical Trials Pilot Program (UL1TR000433; University of Michigan). The authors would like to acknowledge Drs. Feng Wang (ITI scholar), Alejandro Lanis (ITI scholar), and Benjamin Cornwall for their clinical support and Drs. Sunil Kapila and Scott Conley for their intellectual contributions. Additionally, the authors would like to acknowledge MICHR and the University of Michigan School of Dentistry's Clinical Research Core for their regulatory, administrative, and technical support.

\section{FIGURE LEGENDS}

Figure 1. Trial profile. (a) Consort Diagram of patient distribution, (b) Study timeline.

Figure 2. Control case. (a) Horizontal alveolar ridge deficiency in the anterior maxilla. (b) A block graft harvested from the symphysis was fixed with titanium screws (c) The block graft was covered with particulate allograft. (d) The augmented site was further protected with a collagen membrane. (e) Upon re-entry at 4 months the occlusal view clearly demonstrates the horizontal gain of bone width. (f,g) Two implants placed in a correct oro-facial position. (h) Final prosthesis delivery

Figure 3. Stem cell therapy case (a) Defect of the anterior alveolar ridge (b) Titanium screws in place. (c,d) Ixmyelocel-t mixed with $\beta$-TCP and covered with collagen membrane. (e) Clinical 
situation at 4 month re-entry. (f,g) Dental implants placed into grafted bone. (h) Final prosthesis delivery

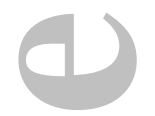

Figure 4. Changes in alveolar ridge width in patients with a history of cleft palate and traumatic injury

\section{Bibliography}

1. Jin LJ, Lamster I, Greenspan JS, Pitts N, Scully C, Warnakulasuriya S. Global burden of oral diseases: emerging concepts, management and interplay with systemic health. Oral Dis 2015.

2. Parker SE, Mai CT, Canfield MA, et al. Updated National Birth Prevalence estimates for selected birth defects in the United States, 2004-2006. Birth Defects Res A Clin Mol Teratol 2010; 88: 1008-1016.

3. Al Jamal GA, Hazza'a AM, Rawashdeh MA. Prevalence of dental anomalies in a population of cleft lip and palate patients. Cleft Palate Craniofac J 2010; 47: 413-420.

4. Glendor U. Aetiology and risk factors related to traumatic dental injuries--a review of the literature. Dent Traumatol 2009; 25: 19-31.

5. Sethi RK, Kozin ED, Fagenholz PJ, Lee DJ, Shrime MG, Gray ST. Epidemiological survey of head and neck injuries and trauma in the United States. Otolaryngol Head Neck Surg 2014; 151: 776-784.

6. Esposito M, Grusovin MG, Felice P, Karatzopoulos G, Worthington HV, Coulthard P. Interventions for replacing missing teeth: horizontal and vertical bone augmentation techniques for dental implant treatment. Cochrane Database Syst Rev 2009: Cd003607.

7. Behnia H, Khojasteh A, Soleimani M, Tehranchi A, Atashi A. Repair of alveolar cleft defect with mesenchymal stem cells and platelet derived growth factors: a preliminary report. $J$ Craniomaxillofac Surg 2012; 40: 2-7.

8. Kaigler D, Pagni G, Park CH, et al. Stem cell therapy for craniofacial bone regeneration: a randomized, controlled feasibility trial. Cell Transplant 2013; 22: 767-777.

9. Kaigler D, Avila-Ortiz G, Travan S, et al. Bone Engineering of Maxillary Sinus Bone Deficiencies Using Enriched CD90+ Stem Cell Therapy: A Randomized Clinical Trial. J Bone Miner Res 2015; 30: 1206-1216.

10. Meijer GJ, de Bruijn JD, Koole R, van Blitterswijk CA. Cell based bone tissue engineering in jaw defects. Biomaterials 2008; 29: 3053-3061.

11. Rajan A, Eubanks E, Edwards S, et al. Optimized cell survival and seeding efficiency for craniofacial tissue engineering using clinical stem cell therapy. Stem Cells Transl Med 2014; 3: 1495-1503. 
12. Gastens MH, Goltry K, Prohaska W, et al. Good manufacturing practice-compliant expansion of marrow-derived stem and progenitor cells for cell therapy. Cell Transplant 2007; 16: 685-696.

13. Connolly JF. Clinical use of marrow osteoprogenitor cells to stimulate osteogenesis. Clin Orthop Relat Res 1998: S257-266.

14. Quarto R, Mastrogiacomo M, Cancedda R, et al. Repair of large bone defects with the use of autologous bone marrow stromal cells. N Engl J Med 2001; 344: 385-386.

15. Hernigou P, Pariat J, Queinnec S, et al. Supercharging irradiated allografts with mesenchymal stem cells improves acetabular bone grafting in revision arthroplasty. Int Orthop 2014; 38: 1913-1921.

16. Kawate $\mathrm{K}$, Yajima $\mathrm{H}$, Ohgushi $\mathrm{H}$, et al. Tissue-engineered approach for the treatment of steroid-induced osteonecrosis of the femoral head: transplantation of autologous mesenchymal stem cells cultured with beta-tricalcium phosphate ceramics and free vascularized fibula. Artif Organs 2006; 30: 960-962.

17. Marcacci M, Kon E, Moukhachev V, et al. Stem cells associated with macroporous bioceramics for long bone repair: 6- to 7-year outcome of a pilot clinical study. Tissue Eng 2007; 13: $947-955$.

18. Warnke PH, Springer IN, Wiltfang J, et al. Growth and transplantation of a custom vascularised bone graft in a man. Lancet 2004; 364: 766-770.

19. Carmichael RP, Sandor GK. Use of dental implants in the management of cleft lip and palate. Atlas Oral Maxillofac Surg Clin North Am 2008; 16: 61-82.

20. Matsui Y, Ohta M, Ohno K, Nagumo M. Alveolar bone graft for patients with cleft lip/palate using bone particles and titanium mesh: A quantitative study. J Oral Maxillofac Surg 2006; 64: 1540-1545.

21. Kim YK, Yeo HH, Kim SG. Use of the tongue flap for intraoral reconstruction: a report of 16 cases. J Oral Maxillofac Surg 1998; 56: 716-719; discussion 720-711.

22. Sandor GK, Carmichael RP, Brkovic BM. Dental implants placed into alveolar clefts reconstructed with tongue flaps and bone grafts. Oral Surg Oral Med Oral Pathol Oral Radiol Endod 2010; 109: e1-7.

23. Wang HL, Boyapati L. "PASS" principles for predictable bone regeneration. Implant Dent 2006; 15: 8-17.

24. Buser D, Dula K, Belser U, Hirt HP, Berthold H. Localized ridge augmentation using guided bone regeneration. 1. Surgical procedure in the maxilla. Int $J$ Periodontics Restorative Dent 1993; 13: 29-45.

25. Buser D, Dula K, Belser UC, Hirt HP, Berthold H. Localized ridge augmentation using guided bone regeneration. II. Surgical procedure in the mandible. Int $J$ Periodontics Restorative Dent 1995; 15: 10-29.

26. Mellonig JT, Nevins M. Guided bone regeneration of bone defects associated with implants: an evidence-based outcome assessment. Int J Periodontics Restorative Dent 1995; 15: 168-185.

27. Artzi Z, Weinreb M, Givol N, et al. Biomaterial resorption rate and healing site morphology of inorganic bovine bone and beta-tricalcium phosphate in the canine: a 24-month longitudinal histologic study and morphometric analysis. Int J Oral Maxillofac Implants 2004; 19 : 357-368.

28. Hak DJ. The use of osteoconductive bone graft substitutes in orthopaedic trauma. J Am Acad Orthop Surg 2007; 15: 525-536.

29. Bajpai I, Kim DY, Kyong-Jin J, Song IH, Kim S. Response of human bone marrowderived MSCs on triphasic Ca-P substrate with various HA/TCP ratio. J Biomed Mater Res $B$ Appl Biomater 2015.

30. Henrich D, Verboket R, Schaible A. Characterization of bone marrow mononuclear cells on biomaterials for bone tissue engineering in vitro. 2015; 2015: 762407. 
31. Ballyns JJ, Bonassar LJ. Image-guided tissue engineering. J Cell Mol Med 2009; 13: 1428-1436.

32. Park $\mathrm{CH}$, Rios HF, Taut $\mathrm{AD}$, et al. Image-based, fiber guiding scaffolds: a platform for regenerating tissue interfaces. Tissue Eng Part C Methods 2014; 20: 533-542.

33. Buser D, Dula K, Hirt HP, Schenk RK. Lateral ridge augmentation using autografts and barrier membranes: a clinical study with 40 partially edentulous patients. J Oral Maxillofac Surg 1996; 54: 420-432; discussion 432-423.

34. da Costa CE, Pelegrine AA, Fagundes DJ, Simoes Mde J, Taha MO. Use of corticocancellous allogeneic bone blocks impregnated with bone marrow aspirate: a clinical, tomographic, and histomorphometric study. Gen Dent 2011; 59: e200-205.

35. Dickinson BP, Ashley RK, Wasson KL, et al. Reduced morbidity and improved healing with bone morphogenic protein-2 in older patients with alveolar cleft defects. Plast Reconstr Surg 2008; 121: 209-217.

36. Pelegrine AA, da Costa CE, Correa ME, Marques JF, Jr. Clinical and histomorphometric evaluation of extraction sockets treated with an autologous bone marrow graft. Clin Oral Implants Res 2010; 21: 535-542.

37. Myeroff C, Archdeacon M. Autogenous bone graft: donor sites and techniques. J Bone Joint Surg Am 2011; 93: 2227-2236.

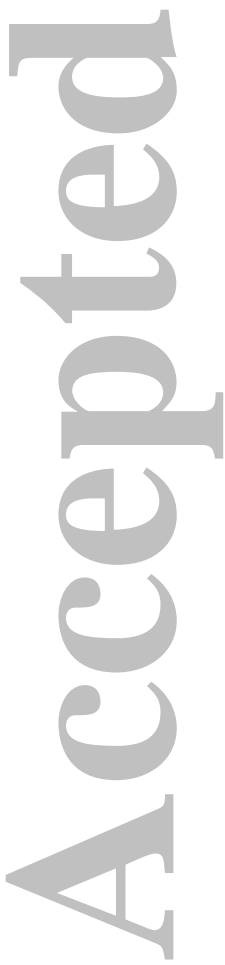

